\title{
Correction to: IL-10-producing regulatory B cells are present and functional in primary Sjögren patients
}

\author{
Julie Mielle ${ }^{1,2}$ Anaïz Nutz ${ }^{1,2}$ Philippe Guillpain ${ }^{3,4} \cdot$ Rachel Audo $^{1,2} \cdot$ Cécile Gaujoux-Viala $^{5}$ - Bernard Combe ${ }^{1,2}$. \\ Jacques Morel $^{1,2} \cdot$ Claire Daien $^{1,2,4}$
}

Published online: 26 February 2021

(C) Springer Science+Business Media, LLC, part of Springer Nature 2021

\section{Correction to: Immunologic Research} https://doi.org/10.1007/s12026-021-09171-x

The first name and last name of the authors in the published version of this article have been exchanged. The correct presentation of their names should be the following: Julie Mielle, Anaïz Nutz, Philippe Guillpain, Rachel Audo, Cécile Gaujoux-Viala, Bernard Combe, Jacques Morel, Claire Daien.

The original article has been corrected.

Publisher's note Springer Nature remains neutral with regard to jurisdictional claims in published maps and institutional affiliations.

The online version of the original article can be found at https://doi.org/ 10.1007/s12026-021-09171-x

Claire Daien

c-daien@chu-montpellier.fr

1 Institute of Molecular Genetics of Montpellier, CNRS, UMR5535, Montpellier, France

2 Department of Rheumatology, Chu of Montpellier, University of Montpellier, Av Doyen G. Giraud, 34295 Montpellier, France

3 Department of Internal Medicine and Multi-Organic Diseases, St Eloi Hospital, Montpellier, France

4 Montpellier University, Medical School, F-34967 Montpellier, France

5 Department of Rheumatology, CHU Nîmes, EA 2415, University of Montpellier, Nîmes, France 